\title{
Appreciation of David Southgate
}

David A T Southgate

(30th August 1932 - 9th May 2008)

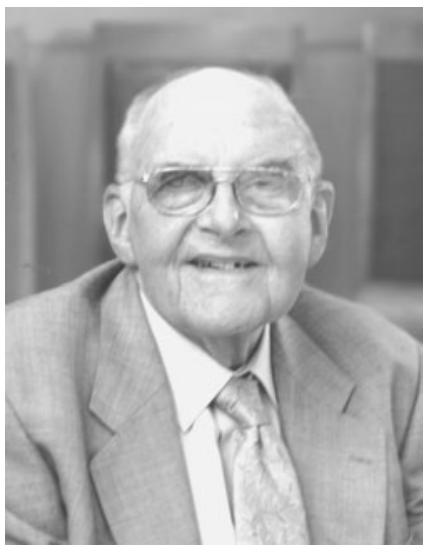

David Southgate will always be known for his work on the composition of foods and the compilation of food tables, and for his innovation in the field of dietary carbohydrate analysis, especially dietary fibre, in which he was the natural heir to McCance and Widdowson, with whom he worked in his early years. He was a chemist and biologist who lived through great changes in the emphasis of nutrition science and major technological advances in the laboratory to become one of the world's most respected figures in his field. A quiet and thoughtful person who gave time to teaching and encouraging the young, but a meticulous and thorough scientist who wanted accurate analytical data about food to be the foundation for an understanding of digestive physiology, energy balance and health.

Dietary carbohydrate analysis was still in its infancy when David joined RA McCance and EM Widdowson (Elsie) in the Department of Experimental Medicine in Cambridge in 1955. Both McCance and Widowson were later to become Fellows of the Royal Society. McCance, the experimental physiologist, brought to this group the need to progress beyond carbohydrate values for food being obtained 'by difference' to more specific measurement of sugars and starch, and a fraction he called 'unavailable carbohydrate'. Elsie was a chemist who had developed methods, in the $1930 \mathrm{~s}$, to measure individual sugars in fruit and vegetables. This was fertile ground for David and he was soon pioneering his own developments in the field. In 1969 he published two papers on carbohydrate analysis in food setting out a comprehensive scheme for their division into 'available' and 'unavailable' fractions. The available group comprised monosaccharides, disaccharides, and starch, measured by a combination of extraction, paper chromatography, acid and enzymatic hydrolysis and colorimetry. Unavailable carbohydrates were those 'not hydrolysed by any enzymes secreted into the human digestive tract ${ }^{\text {(1) }}$. Southgate's scheme was highly innovative, setting out to measure carbohydrates that were insoluble in $85 \%$ methanol but could then be resolved into water soluble polysaccharides (containing hexoses, pentoses and uronic acids), water insoluble hemicellulose, and cellulose, using progressive hydrolysis with sulphuric acid and Takadiastase, methods he had developed for his work on carbohydrates in faeces. The title 'dietary fibre' does not appear in these papers, but by 1972 Hugh Trowell had aligned unavailable carbohydrate with dietary fibre, to distinguish it from crude fibre, used widely in animal nutrition, and thus the dietary fibre concept was born. Both Denis Burkitt and Hugh Trowell, whom I knew well, told me that they used David as their guru on carbohydrates and that the dietary fibre definition grew out of their conversations in 1970 and 1971.

The new methodology for 'fibre' was soon translated into the food tables, along with detailed information about the other carbohydrates. However David was not just a chemist. By 1968 he was at the Dunn Nutrition Unit in Cambridge where in 1975 I arrived, with Philip James, from London, and we were joined soon after by Hans Englyst from Denmark, who had already begun work on his own on dietary carbohydrate analysis, Sheila Bingham, who had a dietetic background and had just published her 'Dictionary of Nutrition', and Alison Stephen, a PhD student, and the scene was set for us to exploit the Southgate methods in an understanding of the nutritional physiology and epidemiology of dietary fibre. There followed an exciting and productive period in all our lives with a series of papers on the effect of fibre on large bowel function, dietary fibre intakes in the UK diet calculated for the first time, effects on mineral bioavailability and lipid metabolism. Whilst this ushered in a new understanding of the role of dietary carbohydrates, problems with alternative methodologies for fibre began to arise and disagreement over the definition spread across the world. In retrospect the term 'unavailable carbohydrate' may have been a mistake combining as it does a difficult to define physiological concept, unavailable, with a precise chemical term, carbohydrate. David, the essential chemist-physiologist, always stood for exact chemistry when it came to determining food composition and was a strong supporter of the move to measure non-starch polysaccharides.

Equally importantly, and perhaps a more enduring legacy, was David's contribution to food tables. The UK tables, known throughout the world as 'McCance and Widdowson' were first published in 1940 and were the fourth of a series of Medical Research Council Special Reports on food composition instigated by RA McCance and RD Lawrence at Kings College Hospital in 1926 to provide information on carbohydrates for the diet of diabetics. The first (1940) edition contained data on the composition of over 200 foods analysed mostly at Kings, but latterly in Cambridge, by a team that from 1933 included Elsie Widdowson and RA McCance. David was taken on in 1955 to help with the 3rd edition, 
now to include processed foods, vitamins and amino acids, and published in 1960. So impressed with David's analytical skills, understanding of nutritional biology and rapidly expanding knowledge, were his mentors, and mindful of the need to revise and update the tables, the Interdepartmental Committee on Food Composition, prompted by Elsie, appointed David to oversee the work for the following edition. On moving to the Dunn Nutrition Unit, after the retirement of McCance in 1966, David was joined by Alison Paul, on secondment from MAFF, and together they produced the 4th edition in 1978, for which around two thirds of foods had been re-analysed. For a while this was known as the Paul and Southgate edition. The amount of routine analytical work became so great that subsequently the tables were produced under the direction of a committee at MAFF using data obtained at the Laboratory of the Government Chemist. The current, 6th edition, compiled under the auspices of the Food Standards Agency was overseen by the Working Party on Nutrients in Food which included Paul and Southgate. These tables have, for more than 60 years, been a major source of reference worldwide to food composition.

David's role in all of this was firstly to carry forward the pioneering work on food composition started by McCance and Widdowson, to introduce new methods, especially for carbohydrates and to maintain the scientific integrity of the data and the best processes for food sampling, analysis and compilation of the tables. But David was also a thoughtful physiologist as well as a chemist and as nutrition developed internationally he worked to try and bring complementarity with other food tables and to make people think about the bioavailability of nutrients and how food tables should be used. As the reputation of the tables grew so did David's authority in the world as probably the most knowledgeable person in the field.

David left the Dunn in 1978 and moved to the Food Research Institute in Norwich with the brief to lead a new human nutrition division. He recruited Sue Fairweather-Tait, Ian Johnson and Sue Southern, who together with Tony Wright worked on folic acid, mineral bioavailability, dietary fibre and resistant starch. By 1989 David had taken on the Editorship of the British Journal of Nutrition, where his regular editorials became a feature of the Journal, and had many international commitments in relation to food tables. His role in Norwich, apart from human nutrition, was to encourage and inspire people to follow their own interests and to mentor the young and help them develop their careers.

On retirement in 1992 David devoted much of his time to teaching whilst continuing to be in demand as an expert in food composition tables. At the invitation of Jo Hautvast he went, with his wife Jean, for 6 months to Wageningen, learning Dutch in the process, where he gave his time readily to the students, talking about all aspects of nutrition and helping them with their writing. Subsequently he returned on many occasions to Europe to teach and mentor the students on the European Nutrition Leadership Programme, which was founded by Jo Hautvast, starting in 1994 in Luxembourg and which will run for the 15th time in 2009. With Clive West he established, in 1992 , a series of international postgraduate courses, held every two years, entitled 'Production and use of food composition data in nutrition' again at Wageningen and with Alison Paul as tutor, the 9th of which will be held in 2009. A similar course is planned to be held in Sydney. He worked closely with international colleagues, including Joanne Holden from the USA FDA, with whom he ran courses on food composition in Wageningen and South Africa.

Academic honours come rarely today to those who work in nutrition, but he was the first winner of 'The British Nutrition Foundation Prize' in 1989, followed by the Royal Society of Chemistry Food Group medal in 1990, the ISFE (International Foundation for the Promotion of Nutrition Research and Nutrition Education) award in 1995 and in 1999 he received a Lifetime Award from the World Cancer Research Fund.

David Alfred Thomas Southgate was born in Woodford Green, Essex to Horace and Winifred Southgate. His father had fought in the battle of the Somme. He attended Southwest Essex Technical School and later College where he first obtained a BSc in general biology, followed by chemistry, graduating finally in 1954. His first job was testing water quality in the Thames from a barge for the London County Council but in 1955 he answered an advert for a research assistant in the Department of Experimental Medicine, Shaftesbury Road, Cambridge with McCance and Widdowson. His PhD thesis in 1965 was entitled 'Carbohydrates in human faecal material'. He moved to the Dunn Nutrition Unit in 1968 and to the Food Research Institute in Norwich in 1978 from where he retired in 1992. In 1957 he married Jean Newton, a childhood friend whom he met through the mutual membership of their families at the Woodford Green United Free Church. They had two children and now two grandchildren. David enjoyed painting in oils and with the money from one of his science prizes built a garden studio.

David suffered from asthma, but seldom complained, and for someone who achieved so much remained modest and approachable throughout his life. He leaves behind a large number of family, friends and people in the world of nutrition who will always speak well of him and whose kindly and avuncular demeanour was always backed by a demand for scientific rigour.

David had many scientific interests beyond carbohydrates and food composition including the energy value of foods, coronary heart disease, bile acid and lipid metabolism, foetal composition, the analysis of the breast milk of primates and other animal species including elephant and hippopotamus, diabetes, and colorectal cancer. He wrote three notable books, on 'Dietary Fibre Analysis' in 1994 and 'Determination of Food Carbohydrate' in 1976 (second edition 1991), and with Heather Greenfield 'Food Composition Data: Production, Management and Use' and was an author of over 200 papers, reviews, chapters and editorials, including one in Nature with Sheila Bingham in 1978. He published five papers that have, as of July 1 2008, received more than 200 citations $^{(1-5)}$.

\section{Acknowledgements}

My thanks are due to Alison Paul, Jo Hautvast, Lous Duym, Paul Trayhurn, Alison Stephen, Sue Fairweather-Tate, Ian Johnson, Philip James and especially Jean Southgate who have provided me with information about and insights into the life of Professor Southgate. 
John H Cummings

Dundee

E-mail: j.h.cummings@dundee.ac.uk

\section{References}

1. Southgate DAT (1969) Determination of carbohydrates in foods II. Unavailable carbohydrates. J Sci Food Agric 20, 331-335.

2. Southgate DAT \& Durnin JVGA (1970) Calorie conversion factors. An experimental reassessment of the factors used in the calculation of the energy value of human diets. Br J Nutr 24, 517-535.
3. Cummings JH, Southgate DAT, Branch W, Houston H, Jenkins DJA \& James WPT (1978) The colonic response to dietary fibre from carrot, cabbage, apple, bran and guar gum. Lancet i, 5-9.

4. Cummings JH, Southgate DAT, Branch W, Wiggins HS, Houston H, Jenkins DJA, Jivraj T \& Hill MJ (1979) The digestion of pectin in the human gut and its effect on calcium absorption and large bowel function. Br J Nutr 41, $477-485$.

5. Ulbricht TLV \& Southgate DAT (1991) Coronary heart disease. 7 dietary factors. Lancet 338, 985-992. 